\title{
Increased HSP70 and TLR2 Gene Expression and Association of HSP70 rs6457452 Single Nucleotide Polymorphism with the Risk of Chronic Obstructive Pulmonary Disease in the Croatian Population
}

\author{
Iva Hlapčić ${ }^{1}$, Marija Grdić Rajković ${ }^{1}$, Andrea Čeri ${ }^{1}$, Sanja Dabelić ${ }^{2}$, Sanja Popović-Grle ${ }^{3,4}$, \\ Margareta Radić Antolic ${ }^{5}$, Jelena Knežević ${ }^{6,7}$, Asta Försti ${ }^{8,9}$ (D) and Lada Rumora ${ }^{1, *}$
}

check for updates

Citation: Hlapčić, I.; Grdić Rajković, M.; Čeri, A.; Dabelić, S.; Popović-Grle, S.; Radić Antolic, M.; Knežević, J.; Försti, A.; Rumora, L. Increased HSP70 and TLR2 Gene Expression and Association of HSP70 rs6457452 Single Nucleotide Polymorphism with the Risk of Chronic Obstructive Pulmonary Disease in the Croatian Population. Diagnostics 2021, 11, 1412. https://doi.org/10.3390/

diagnostics11081412

Academic Editor: Fabiano Di Marco

Received: 8 July 2021

Accepted: 2 August 2021

Published: 4 August 2021

Publisher's Note: MDPI stays neutral with regard to jurisdictional claims in published maps and institutional affiliations.

Copyright: (C) 2021 by the authors Licensee MDPI, Basel, Switzerland. This article is an open access article distributed under the terms and conditions of the Creative Commons Attribution (CC BY) license (https:// creativecommons.org/licenses/by/ $4.0 /)$.
1 Department of Medical Biochemistry and Haematology, Faculty of Pharmacy and Biochemistry, University of Zagreb, 10000 Zagreb, Croatia; iva.hlapcic@pharma.unizg.hr (I.H.); mgrdic@pharma.hr (M.G.R.); andrea.ceri@pharma.unizg.hr (A.Č.)

2 Department of Biochemistry and Molecular Biology, Faculty of Pharmacy and Biochemistry, University of Zagreb, 10000 Zagreb, Croatia; sanja.dabelic@pharma.unizg.hr

3 Clinical Department for Lung Diseases Jordanovac, University Hospital Centre Zagreb, 10000 Zagreb, Croatia; spopovi1@kbc-zagreb.hr

4 School of Medicine, University of Zagreb, 10000 Zagreb, Croatia

5 Clinical Institute of Laboratory Diagnostics, University Hospital Centre Zagreb, 10000 Zagreb, Croatia; mradicantolic@gmail.com

6 Ruđer Bošković Institute, Division of Molecular Medicine, Laboratory for Advanced Genomics, 10000 Zagreb, Croatia; Jelena.Knezevic@irb.hr

7 Department of Integrative Medicine, Faculty for Dental Medicine and Health, Josip Juraj Strossmayer University of Osijek, 31000 Osijek, Croatia

8 German Cancer Research Center (DKFZ), German Cancer Consortium (DKTK), Division of Pediatric Neuroon-Cology, 69120 Heidelberg, Germany; a.foersti@kitz-heidelberg.de

9 Hopp Children's Cancer Center (KiTZ), 69120 Heidelberg, Germany

* Correspondence: lada.rumora@pharma.unizg.hr; Tel.: +385-1639-4782; Fax: +385-1461-2716

Abstract: Heat shock protein 70 (Hsp70) engages Toll-like receptors (TLR) 2 and 4 when found in the extracellular compartment and contributes to inflammation in chronic obstructive pulmonary disease (COPD). Since there is growing evidence for the genetic risk factors for COPD, the gene expression of HSP70, TLR2 and TLR4 was determined, as well as the association between HSP70, TLR2 and TLR4 single nucleotide polymorphisms, (SNPs) and COPD. The gene expression was assessed in peripheral blood cells of 137 COPD patients and 95 controls by a quantitative polymerase chain reaction (qPCR), while a total of nine SNPs were genotyped by TaqMan allelic discrimination real-time PCR. HSP70 and TLR2 gene expression was increased in COPD patients compared to the controls, regardless of the disease severity and smoking status of participants. The rs6457452 SNP of HSP70 was associated with COPD, indicating the protective role of the T allele (OR $=0.46$, $95 \% \mathrm{CI}=0.24-0.89, p=0.022)$. Furthermore, COPD C/T heterozygotes showed a decreased HSP70 mRNA level compared to COPD C/C homozygotes. In conclusion, HSP70 and TLR2 may have a role in the pathogenesis of COPD, and the HSP70 rs6457452 variant might influence the genetic susceptibility to COPD in the Croatian population.

Keywords: chronic obstructive pulmonary disease; heat shock protein 70; toll-like receptor 2; toll-like receptor 4; single nucleotide polymorphism

\section{Introduction}

Chronic obstructive pulmonary disease (COPD) is a multicomponent heterogeneous inflammatory disease characterized by persistent respiratory symptoms and airflow limitation [1]. It is known that the development of COPD is influenced by several environmental and genetic factors. Tobacco exposure has been recognized as the main environmental 
risk factor for COPD [2], yet only 10-20\% of smokers develop airway obstruction [3]. COPD has both pulmonary and extrapulmonary manifestations, and systemic chronic inflammation has been identified as a potential COPD endotype [4]. It is considered that the persistent low-grade inflammation in stable COPD might be caused by increased levels of many inflammatory mediators [5], reactive oxygen and nitrogen species [6], and pathogen-associated molecular patterns or damage-associated molecular patterns (DAMPs) such as extracellular heat shock protein 70 (eHsp70) [7-9]. eHsp70 is thought to activate proinflammatory responses by binding to Toll-like receptors (TLRs) 2 and 4 , leading to increased cytokines concentrations [10].

Hsp70 is predominantly an intracellular protein involved in the maintenance of protein homeostasis, especially in the presence of stressors such as heat, bacterial, and viral infections [11]. However, the role of Hsp70 in COPD pathogenesis remains to be elucidated. Increased gene expression of $H S P 70$ and its protein concentration was observed in lung tissues of COPD patients, and HSP70 mRNA levels were negatively correlated with lung function. Moreover, HSP70 expression in lung tissues was associated with airway obstruction severity and smoking status [12]. In the study by Ambrocio-Ortiz et al., expression of $H S P 70$ was examined in sputum, and they found a decrease in the COPD smoking group compared to controls who were mostly smokers [13].

Considering TLR2 and TLR4, they are expressed by a variety of cells involved in innate and adaptive immune responses. Cigarette smoke and Hsps can affect TLR2 and TLR4 protein concentration and the mRNA level in the respiratory tract. Our previous study showed that cigarette smoke or eHsp70 can inhibit the expression of TLR2 and TLR4 in bronchial epithelial cells in COPD [14]. Moreover, TLR2 and TLR4 expression was decreased in the lung parenchyma of COPD patients with severe disease, while the gene expression of both receptors was increased in the airway epithelium of COPD patients in mild and moderate stages [15]. However, when TLR2 and TLR4 gene expression was determined in alveolar macrophages from the bronchoalveolar lavage of COPD smokers, there was no difference in the mRNA levels compared to both the control of non-smokers and control of smokers [16].

In general, the gene expression could differ in various types of samples used in the analysis. Sputum reflects the central airways, while bronchoalveolar lavage represents the peripheral airways [17]. On the other hand, blood is an easily available sample that is representative of systemic compartment, which is also important in COPD. To the best of our knowledge, this is the first study in which blood samples were used to assess the basal HSP70, TLR2 and TLR4 gene expression in stable COPD without any further in vitro treatments or stimulations.

COPD is a complex disease with a genetic background. Single nucleotide polymorphisms (SNPs) may be associated with changes in gene expression, affect gene product and thus contribute to susceptibility to disease. HSP70 polymorphisms have been found to be related to various diseases such as pulmonary fibrosis [18,19], atherosclerosis [20], coronary heart disease [21] and COPD [13]. Furthermore, the HSP70 rs1061581 variant was associated with COPD in the Croatian population [22]. Genetic polymorphisms in TLR2 and TLR4 genes were also significantly related to altered risk of COPD [23-25] as well as to reduced lung function and an increased number of inflammatory cells in the sputum of COPD patients [24].

The aim of this study was to investigate the gene expression of HSP70, TLR2 and TLR4 in the peripheral blood cells of COPD patients and to explore whether there is an association between the gene expression and disease severity, and smoking. Genotype and allele distribution of selected HSP70, TLR2 and TLR4 polymorphisms were determined in healthy subjects and COPD patients, and a potential association between SNPs and COPD was assessed. Finally, we explored the relation between HSP70, TLR2 and TLR4 mRNA levels, and investigated polymorphisms. 


\section{Materials and Methods}

\subsection{Study Population}

The retrospective study comprised of 137 COPD patients in the stable phase of the disease, and 95 controls. Stable COPD was defined as no exacerbations during at least three physician visits in the previous 3 months, with no changes in respiratory therapy and no symptoms of a lower respiratory tract infection. All participants were recruited at the Clinical Department for Lung Diseases Jordanovac, University Hospital Centre Zagreb (Zagreb, Croatia) after they agreed to participate voluntarily in the study and signed an informed consent form. The study was approved by the Ethical Committee of the University Hospital Centre Zagreb and the Ethical Committee for Experimentation of the University of Zagreb Faculty of Pharmacy and Biochemistry (Zagreb, Croatia) (approval protocol numbers: 02/21/JG on 29 August 2014 and 251-62-03-14-78 on 10 September 2014, respectively).

The diagnosis of COPD was made according to the guidelines [1], after measuring the spirometry parameters-forced expiratory volume in the first second $\left(\mathrm{FEV}_{1}\right)$ and forced vital capacity (FVC). If $\mathrm{FEV}_{1} / \mathrm{FVC}$ was under the value of 0.70 , airway obstruction was confirmed. COPD patients were classified into GOLD stages based on $\mathrm{FEV}_{1}$ as follows: GOLD $1\left(\mathrm{FEV}_{1} \geq 80 \%\right)(n=0), \mathrm{GOLD}_{2}\left(50 \% \leq \mathrm{FEV}_{1}<80 \%\right)(n=47), \mathrm{GOLD}_{3}\left(30 \% \leq \mathrm{FEV}_{1}<50 \%\right)$ $(n=50)$ and GOLD $4\left(\mathrm{FEV}_{1}<30 \%\right)(n=40)$. In addition to airflow limitation severity, data on symptoms severity and history of exacerbations were used to differentiate COPD patients into GOLD groups based on COPD Assessment Test (CAT). There were GOLD A $(n=27)$, GOLD B $(n=70)$, GOLD C $(n=0)$ and GOLD D $(n=40)$ groups.

The control subjects were age- and sex-matched with the COPD subjects, and their medical history data and spirometry results were used to determine their health status. Subjects in both groups were older than 40 years, had no lung diseases (except COPD in COPD patients), inflammatory systemic diseases, acute infections, diabetes with severe complications, severe liver disease, severe renal insufficiency, malignant diseases, transplantations, or other specific or non-specific acute inflammation. In addition, all participants provided information on smoking status, so that there were 48 healthy non-smokers, 47 healthy smokers, 10 COPD non-smokers, 90 COPD former smokers, and 37 COPD smokers.

\subsection{RNA Isolation and Gene Expression Analysis}

Blood samples were collected in two tubes containing ethylenediaminetetraacetic acid (EDTA) anticoagulant (Greiner Bio-One, GmbH, Kremsmünster, Austria). One tube was used for DNA isolation, while the other was used for RNA extraction. After centrifugation at $3500 \mathrm{rpm}$ for $10 \mathrm{~min}$ at $+4{ }^{\circ} \mathrm{C}$, RNA was extracted from buffy coat using the TRIzol/chloroform method [26], followed by the cDNA synthesis using RevertAid First Strand cDNA Synthesis Kit (Thermo Fischer Scientific, Waltham, MA, USA) with the GeneAmp PCR System 9700 (Applied Biosystems, Foster City, CA, USA) [27]. Commercial TaqMan Gene Expression Assays were used for the assessment of gene expression (Hs00359163_s1 for HSP70, Hs02621280_s1 for TLR2, Hs00152939_m1 for TLR4; Applied Biosystems, Foster City, CA, USA) as well as Taqman Universal Master Mix (Applied Biosystems, Foster City, CA, USA), according to the manufacturer's guidelines. Beta-2-microglobulin (B2M) and peptidylprolyl isomerase (PPIA) ((Hs99999907_m1 for B2M, Hs99999904_m1for PPIA; Applied Biosystems, Foster City, CA, USA) were used as the endogenous controls for data normalization. The $2^{-\Delta \Delta \mathrm{Ct}}$ method was used to calculate the relative expression of target genes in controls and COPD patients [28]. One randomly chosen control sample was included in each plate as a calibrator.

\subsection{Determination of eHsp70 Concentration}

Measurement of eHsp70 was determined in the same cohort in our previous study (8) in EDTA plasma using the commercially available enzyme-linked immunosorbent assay (ELISA) kit (Enzo Life Science, Farmingdale, NY, USA). 


\subsection{DNA Isolation and SNP Genotyping}

DNA was extracted from blood cells by a standard salting-out procedure [29]. SNPs in the HSP70,TLR2 and TLR4 genes were selected based on a literature search of studies associated with COPD, smoking or other respiratory diseases, and when the minor allele frequency was (MAF) $\geq 0.05$ in the European population, according to the 1000 Genomes Project. A total of nine polymorphisms shown in Table 1 were selected for genotyping by the Taqman allelic discrimination real-time PCR. Reaction was carried out in a total volume of $10 \mu \mathrm{L}$ with the corresponding SNP Genotyping Assays (Applied Biosystems, Waltham MA, USA), TaqMan Genotyping Master Mix (Applied Biosystems, Foster City, CA, USA), and an adjusted volume of DNA templates, according to the manufacturer's instructions. Analysis was performed in a 7500 Real-Time PCR System (Applied Biosystems, Foster City, CA, USA) using a default PCR amplification protocol. The successful call rate was greater than $96 \%$, while $10 \%$ of samples were genotyped additionally to assess the reproducibility of the genotyping protocol. Data were interpreted using the Sequence Detection Software (SDS v. 1.4., Applied Biosystems, Waltham, MA, USA).

Table 1. Basic information about investigated polymorphisms in HSP70, TLR2 and TLR4 genes.

\begin{tabular}{|c|c|c|c|c|c|c|c|}
\hline Gene Name & Gene ID & SNP ID & Assay ID & Functional Relevance & $\begin{array}{l}\text { Nucleotide } \\
\text { Substitution }\end{array}$ & $\begin{array}{c}\text { Chromosome } \\
\text { Position }\end{array}$ & MAF \\
\hline HSPA1A & 3303 & rs1008438 & ANCFDUH * & $2 \mathrm{~KB}$ upstream variant & $A>C$ & chr6:31815431 & $0.4036(\mathrm{C})$ \\
\hline HSPA1A & 3303 & rs1043618 & C_11917510_10 & 5'UTR variant & $\mathrm{G}>\mathrm{C}$ & chr6:31815730 & $0.3926(\mathrm{C})$ \\
\hline HSPA1B & 3304 & rs6457452 & C__3052604_10 & $5^{\prime}$ UTR variant & $\mathrm{C}>\mathrm{T}$ & chr6:31827773 & $0.0775(\mathrm{~T})$ \\
\hline TLR2 & 7097 & rs1898830 & C_11853988_10 & intron variant & $A>G$ & chr4:153687301 & $0.3250(\mathrm{G})$ \\
\hline TLR2 & 7097 & rs3804099 & C_22274563_10 & synonymous variant & $\mathrm{T}>\mathrm{C}$ & chr4:153703504 & $0.4354(\mathrm{C})$ \\
\hline TLR2 & 7097 & rs13150331 & C_11853987_10 & intron variant & $A>G$ & chr4:153678470 & $0.4056(\mathrm{G})$ \\
\hline TLR4 & 7099 & rs2737190 & C__2704047_10 & upstream variant & $G>A$ & chr9:117701903 & $0.3290(\mathrm{G})$ \\
\hline TLR4 & 7099 & rs10759932 & C_31783996_10 & $2 \mathrm{~KB}$ upstream variant & $\mathrm{T}>\mathrm{C}$ & chr9:117702866 & $0.1531(\mathrm{C})$ \\
\hline TLR4 & 7099 & rs7846989 & C_189478937_10 & 3'UTR variant & $\mathrm{T}>\mathrm{C}$ & chr9:117720662 & $0.1004(\mathrm{C})$ \\
\hline
\end{tabular}

HSP—heat shock protein; TLR—Toll like receptor; SNP—single nucleotide polymorphism; MAF-minor allele frequency (1000 Genomes, European population); UTR-untranslated. ${ }^{*}$ Custom Taqman ${ }^{(R)}$ SNP Genotyping Assay.

\subsection{Statistics}

Data were analyzed using MedCalc statistical software version 17.9.2. (MedCalc Software, Ostend, Belgium). All data failed a normality test performed with the KolmogorovSmirnov test, so a nonparametric Mann-Whitney test was used to assess the differences in age, spirometry parameters and the relative expression of target genes between the controls and COPD subjects. The Kruskal-Wallis test was used when more than two groups were compared. $\chi^{2}$ test was used to compare the categorical variable (sex), while the $\chi^{2}$ and Fisher's exact test were used to test the relation between genotype and allele distribution. Logistic regression was performed for an association analysis between genotype and allele distribution, and COPD risk by calculating the odds ratio (OR) and the corresponding 95\% confidence interval (CI).

The SNPStats software (https:/ / www.snpstats.net/start.htm, accessed on 15 October 2020) was used for the assessment of Hardy-Weinberg equilibrium (HWE), linkage disequilibrium (LD), and haplotype analysis. A strong LD was considered when $\mathrm{D}^{\prime}>0.80$ [30].

The $p$ value of $<0.05$ was considered statistically significant in all analyses.

\section{Results}

\subsection{Basic Population Characteristics}

The general information and spirometry results of the enrolled participants are shown in Table 2. COPD patients had decreased values of spirometry parameters in comparison to the controls. There was no difference in age or sex distribution between the two groups. 
Table 2. Basic characteristics and spirometry parameters of healthy controls and COPD patients included in the study.

\begin{tabular}{cccc}
\hline Parameter & $\begin{array}{c}\text { Controls } \\
(\boldsymbol{n}=\mathbf{9 5})\end{array}$ & $\begin{array}{c}\text { COPD Patients } \\
(\boldsymbol{n}=\mathbf{1 3 7})\end{array}$ & $p$ \\
\hline sex & 49 & 86 & 0.118 \\
male & 46 & 51 & 0.073 \\
\hline female & $64(46-83)$ & $65(44-86)$ & $<0.001$ \\
\hline age & 2.60 & 1.08 & $<0.001$ \\
\hline FEV 1 (L) & $(2.12-3.19)$ & $(0.78-1.57)$ & $<0.001$ \\
\hline $\mathrm{FEV}_{1}(\%$ predicted $)$ & 93 & 39 & $<0.001$ \\
\hline FVC $(\mathrm{L})$ & $(86-104)$ & $(28-60)$ & 2.28 \\
\hline $\mathrm{FEV}_{1} / \mathrm{FVC}(\%)$ & 3.35 & $(1.81-2.77)$ & 48 \\
\hline
\end{tabular}

COPD—chronic obstructive pulmonary disease; $\mathrm{FEV}_{1}$ —-forced expiratory volume in the first second; FVC—forced vital capacity.

Age is shown as a median (minimum and maximum), while sex is shown as an absolute number. Other results are presented as a median (interquartile range). Data were analyzed by the $\chi^{2}$ or Mann-Whitney test.

\subsection{HSP70, TLR2 and TLR4 Gene Expression in Controls and COPD Patients}

The gene expression of HSP70, TLR2 and TLR4 was determined in peripheral blood cells, and it was found that the mRNA level was increased for HSP70 and TLR2 in patients with COPD, when compared to healthy subjects (Table 3).

Table 3. Relative expression of HSP70, TLR2 and TLR4 in controls and COPD patients.

\begin{tabular}{cccc}
\hline & Controls & COPD Patients & $p$ \\
\hline \multirow{2}{*}{ HSP70 } & 1.01 & 1.73 & $<0.001$ \\
& $(0.74-2.07)$ & $(1.11-7.46)$ & 0.002 \\
\hline \multirow{2}{*}{ TLR2 } & 1.03 & 1.93 & 0.323 \\
& $(0.69-2.65)$ & $(0.95-6.10)$ & 0.77 \\
\multirow{2}{*}{ TLR4 } & 0.72 & $(0.56-1.07)$ & \multirow{2}{*}{$0.56-0.94)$}
\end{tabular}

HSP70—-heat shock protein 70; TLR—Toll like receptor; COPD—chronic obstructive pulmonary disease. Data were analyzed by Mann-Whitney test and shown as a median (interquartile range).

Regarding the severity of airway obstruction as well as symptoms burden and the history of exacerbations (assessed by CAT), the gene expression of HSP70 and TLR2 was up-regulated in GOLD 2, GOLD 3 and GOLD 4 stages as well as in GOLD A, GOLD B and GOLD D groups, respectively, in comparison to the control group (Table 4). However, no significant differences between GOLD stages or groups were found.

HSP70 gene expression showed to be increased in COPD non-smokers, COPD former smokers and COPD smokers in comparison to healthy non-smokers (Table 5). On the other hand, there was no difference between COPD non-smokers and healthy smokers, while the HSP70 mRNA level was increased in COPD former and current smokers compared to healthy smokers. However, HSP70 expression amongst COPD patients was independent of their smoking history. TLR2 expression was increased in former COPD smokers and COPD smokers in comparison to healthy non-smokers, and only in COPD smokers when compared to healthy smokers. On the other hand, gene expression of TLR4 did not differ between controls and COPD patients with different smoking history. 
Table 4. Relative expression of HSP70, TLR2 and TLR4 in controls and COPD patients according to the severity of airflow obstruction and symptoms severity.

\begin{tabular}{|c|c|c|c|c|c|c|c|c|c|}
\hline & $\begin{array}{c}\text { Controls } \\
(n=95)\end{array}$ & $\begin{array}{l}\text { GOLD } 2 \\
(n=47)\end{array}$ & $\begin{array}{l}\text { GOLD } 3 \\
(n=50)\end{array}$ & $\begin{array}{l}\text { GOLD } 4 \\
(n=40)\end{array}$ & $p^{1}$ & $\begin{array}{c}\text { GOLD A } \\
(n=27)\end{array}$ & $\begin{array}{l}\text { GOLD B } \\
(n=70)\end{array}$ & $\begin{array}{l}\text { GOLD D } \\
(n=40)\end{array}$ & $p^{2}$ \\
\hline HSP70 & $\begin{array}{c}1.01 \\
(0.74-2.07)\end{array}$ & $\begin{array}{c}1.67 \\
(1.00-10.21)\end{array}$ & $\begin{array}{c}1.92 \\
(1.22-12.09)\end{array}$ & $\begin{array}{c}1.68 \\
(1.06-5.50)\end{array}$ & $<0.001$ & $\begin{array}{c}1.72 \\
(1.12- \\
11.61)\end{array}$ & $\begin{array}{c}1.67 \\
(1.09-6.04)\end{array}$ & $\begin{array}{c}2.79 \\
(1.17-7.46)\end{array}$ & $<0.001$ \\
\hline TLR2 & $\begin{array}{c}1.03 \\
(0.69-2.65)\end{array}$ & $\begin{array}{c}1.83 \\
(1.00-3.67)\end{array}$ & $\begin{array}{c}1.96 \\
(1.02-10.64)\end{array}$ & $\begin{array}{c}1.83 \\
(0.90-6.92)\end{array}$ & 0.019 & $\begin{array}{c}1.89 \\
(1.18-5.26)\end{array}$ & $\begin{array}{c}1.63 \\
(0.82-3.81)\end{array}$ & $\begin{array}{c}2.11 \\
(1.00-8.51)\end{array}$ & 0.009 \\
\hline TLR4 & $\begin{array}{c}0.72 \\
(0.56-0.94)\end{array}$ & $\begin{array}{c}0.78 \\
(0.61-1.07)\end{array}$ & $\begin{array}{c}0.80 \\
(0.56-1.09)\end{array}$ & $\begin{array}{c}0.71 \\
(0.56-0.99)\end{array}$ & 0.690 & $\begin{array}{c}0.76 \\
(0.59-1.06)\end{array}$ & $\begin{array}{c}0.76 \\
(0.56-1.09)\end{array}$ & $\begin{array}{c}0.80 \\
(0.56-0.98)\end{array}$ & 0.797 \\
\hline
\end{tabular}

HSP70-heat shock protein 70; TLR - Toll like receptor; COPD_chronic obstructive pulmonary disease; GOLD-Global Initiative for Chronic Obstructive Pulmonary Disease. Results are shown as a median (interquartile range). $p^{1}$-comparison between controls and GOLD 2-4 by Kruskal-Wallis test; $p^{2}$-comparison between controls and GOLD A-D by Kruskal-Wallis test.

Table 5. Relative expression of HSP70, TLR2 and TLR4 in controls and COPD patients based on smoking status.

\begin{tabular}{|c|c|c|c|c|c|c|}
\hline & $\begin{array}{c}\text { Healthy } \\
\text { Non-Smokers } \\
(n=48)\end{array}$ & $\begin{array}{l}\text { Healthy } \\
\text { Smokers } \\
(n=47)\end{array}$ & $\begin{array}{c}\text { COPD } \\
\text { Non-Smokers ( } n \\
=10)\end{array}$ & $\begin{array}{l}\text { COPD Former } \\
\text { Smokers } \\
(n=90)\end{array}$ & $\begin{array}{l}\text { COPD Smokers } \\
\quad(n=37)\end{array}$ & $p$ \\
\hline HSP70 & $\begin{array}{c}0.93 \\
(0.64-1.78)\end{array}$ & $\begin{array}{c}1.09 \\
(0.90-2.07)\end{array}$ & $\begin{array}{c}1.87^{\mathrm{a}} \\
(1.49-2.11)\end{array}$ & $\begin{array}{c}1.72^{\mathrm{a}, \mathrm{b}} \\
(1.05-6.53)\end{array}$ & $\begin{array}{c}2.14^{\mathrm{a}, \mathrm{b}} \\
(1.21-12.93)\end{array}$ & $<0.001$ \\
\hline TLR2 & $\begin{array}{c}0.98 \\
(0.70-3.08) \\
\end{array}$ & $\begin{array}{c}1.18 \\
(0.65-2.65) \\
\end{array}$ & $\begin{array}{c}2.22 \\
(1.17-3.94) \\
\end{array}$ & $\begin{array}{c}1.81^{\mathrm{a}} \\
(0.86-6.34) \\
\end{array}$ & $\begin{array}{c}1.98^{\mathrm{a}, \mathrm{b}} \\
(1.32-12.59)\end{array}$ & 0.022 \\
\hline TLR4 & $\begin{array}{c}0.65 \\
(0.54-0.93)\end{array}$ & $\begin{array}{c}0.78 \\
(0.63-0.96)\end{array}$ & $\begin{array}{c}0.78 \\
(0.61-1.07)\end{array}$ & $\begin{array}{c}0.80 \\
(0.56-1.09)\end{array}$ & $\begin{array}{c}0.71 \\
(0.56-0.99)\end{array}$ & 0.482 \\
\hline
\end{tabular}

HSP70-heat shock protein 70; TLR—Toll like receptor; COPD—chronic obstructive pulmonary disease. Data were tested by Kruskal-Wallis test and shown as median (interquartile range). ${ }^{a}$ statistically significant difference in comparison to healthy non-smokers; ${ }^{b}$ statistically significant difference in comparison to healthy smokers.

\subsection{Association Analysis between HSP70, TLR2 and TLR4 SNPs and COPD}

A total of nine SNPs of the HSP70, TLR2 and TLR4 genes were examined, and all SNPs had a call rate $>96 \%$. The genotype frequency distributions were consistent with HWE $(p>0.05)$, except for the TLR2 rs1898830 SNP, so this variant was not included in further statistical analysis. Genotype and allele distribution of the studied polymorphisms was determined, and an association analysis was performed. It was found that the HSP70 rs6457452 variant was associated with COPD risk when $\mathrm{C} / \mathrm{T}$ and $\mathrm{T} / \mathrm{T}$ carriers $(\mathrm{OR}=0.48$, $95 \% \mathrm{CI}=0.24-0.97, p=0.040$ ) were compared to $\mathrm{C} / \mathrm{C}$ carriers (Table 6). In addition, there was a significant difference in allele distribution, and the $\mathrm{T}$ allele showed OR of $0.46(95 \% \mathrm{CI}=0.24-0.89, p=0.022)$ in comparison to the reference $\mathrm{C}$ allele. However, no significant relation between TLR2 and TLR4 polymorphisms and the risk of COPD was found (Table 6).

The associations between gene expression and polymorphisms of each gene were then examined. HSP70 expression was increased in COPD C/C carriers of the rs6457452 polymorphism compared to COPD C/T carriers as well as in comparison to control C/C carriers (Table 7). On the other hand, relative gene expression of HSP70 did not differ in the carriers of the $\mathrm{C} / \mathrm{T}$ genotype when controls and COPD patients were compared. Reference homozygotes and heterozygotes of rs1008438 and rs1043618 who were COPD patients showed increased HSP70 gene expression, while there was no difference in HSP70 expression between control subjects and the COPD patient group within the variant homozygotes. The same was observed regarding the TLR2 rs3804099 polymorphism, while the COPD carriers of the G/G genotype of the rs13150331 showed increased TLR2 expression in comparison to healthy participants with the same genotype (Table S1). Finally, since TLR4 expression did not differ between controls and COPD patients, there were no significant 
observations when TLR4 expression was analyzed with respect to the three TLR4 SNPs in all participants (Table S2).

Table 6. Genotype and allele distribution of HSP70, TLR2 and TLR4 polymorphisms in controls and COPD patients, and association analysis between investigated polymorphisms and COPD risk.

\begin{tabular}{|c|c|c|c|c|c|c|c|}
\hline HSP70 & & & $\begin{array}{c}\text { Controls } \\
\text { n (\%) }\end{array}$ & $\begin{array}{c}\text { COPDn } \\
(\%)\end{array}$ & $p^{1}$ & OR $(95 \%$ CI $)$ & $p^{2}$ \\
\hline \multirow{5}{*}{ rs1008438 } & \multirow{3}{*}{ genotype } & $\mathrm{A} / \mathrm{A}$ & $33(35)$ & $60(44)$ & \multirow{3}{*}{0.192} & 1.00 & \\
\hline & & $\mathrm{A} / \mathrm{C}$ & $50(54)$ & $57(41)$ & & $0.61(0.34-1.08)$ & 0.089 \\
\hline & & $\mathrm{C} / \mathrm{C}$ & $10(11)$ & $20(15)$ & & $0.97(0.41-2.27)$ & 0.943 \\
\hline & \multirow{2}{*}{ allele } & $\mathrm{A}$ & $116(62)$ & 177 (65) & \multirow[b]{2}{*}{0.697} & 1.00 & \multirow[b]{2}{*}{0.625} \\
\hline & & $\mathrm{C}$ & $70(38)$ & $97(35)$ & & $0.91(0.62-1.34)$ & \\
\hline \multirow{5}{*}{ rs1043618 } & \multirow{3}{*}{ genotype } & $\mathrm{G} / \mathrm{G}$ & $33(36)$ & $61(45)$ & \multirow{3}{*}{0.315} & 1.00 & \\
\hline & & $\mathrm{C} / \mathrm{G}$ & $46(51)$ & $55(40)$ & & $0.65(0.36-1.15)$ & 0.139 \\
\hline & & $\mathrm{C} / \mathrm{C}$ & $12(13)$ & $20(15)$ & & $0.90(0.39-2.07)$ & 0.807 \\
\hline & \multirow{2}{*}{ allele } & $G$ & $112(62)$ & $177(65)$ & \multirow[b]{2}{*}{0.504} & 1.00 & \multirow[b]{2}{*}{0.443} \\
\hline & & $\mathrm{C}$ & $70(38)$ & $95(35)$ & & $0.86(0.58-1.27)$ & \\
\hline \multirow{5}{*}{ rs6457452 } & \multirow{3}{*}{ genotype } & $\mathrm{C} / \mathrm{C}$ & $71(77)$ & $120(88)$ & \multirow{3}{*}{0.046} & 1.00 & \multirow{3}{*}{0.040} \\
\hline & & $\mathrm{C} / \mathrm{T}$ & $19(21)$ & 17 (12) & & & \\
\hline & & $\mathrm{T} / \mathrm{T}$ & $2(2)$ & $0(0)$ & & $0.48(0.24-0.97)$ & \\
\hline & \multirow{2}{*}{ allele } & $\mathrm{C}$ & $161(88)$ & $257(94)$ & \multirow[b]{2}{*}{0.030} & 1.00 & \multirow[b]{2}{*}{0.022} \\
\hline & & $\mathrm{T}$ & $23(12)$ & $17(6)$ & & $0.46(0.24-0.89)$ & \\
\hline \multicolumn{8}{|l|}{ TLR2 } \\
\hline \multirow{5}{*}{ rs3804099 } & \multirow{3}{*}{ genotype } & $\mathrm{T} / \mathrm{T}$ & $29(32)$ & $45(33)$ & \multirow{3}{*}{0.668} & 1.00 & \\
\hline & & $\mathrm{C} / \mathrm{T}$ & $44(48)$ & $59(43)$ & & $0.86(0.47-1.59)$ & 0.638 \\
\hline & & $\mathrm{C} / \mathrm{C}$ & $18(20)$ & $33(24)$ & & $1.18(0.56-2.48)$ & 0.659 \\
\hline & \multirow[b]{2}{*}{ allele } & $\mathrm{T}$ & $102(56)$ & $149(54)$ & & 1.00 & \\
\hline & & $\mathrm{C}$ & $80(44)$ & $125(46)$ & 0.800 & $1.07(0.73-1.56)$ & 0.726 \\
\hline & & $\mathrm{A} / \mathrm{A}$ & $27(29)$ & $48(36)$ & & 1.00 & \\
\hline & genotype & $\mathrm{A} / \mathrm{G}$ & $48(52)$ & $60(44)$ & 0.547 & $0.73(0.39-1.34)$ & 0.310 \\
\hline rs13150331 & & $\mathrm{G} / \mathrm{G}$ & 17 (19) & $27(20)$ & & $0.95(0.44-2.06)$ & 0.903 \\
\hline & & A & $102(55)$ & $156(58)$ & & 1.00 & \\
\hline & allele & G & $82(45)$ & $114(42)$ & 0.690 & $0.91(0.62-1.33)$ & 0.621 \\
\hline TLR4 & & & & & & & \\
\hline & & $\mathrm{G} / \mathrm{G}$ & $14(15)$ & $19(14)$ & & 1.00 & \\
\hline & genotype & $\mathrm{A} / \mathrm{G}$ & $35(38)$ & $59(45)$ & 0.600 & $1.24(0.55-2.78)$ & 0.599 \\
\hline rs2737190 & & $\mathrm{A} / \mathrm{A}$ & $43(47)$ & $54(41)$ & & $0.92(0.42-2.06)$ & 0.849 \\
\hline & & G & $63(34)$ & $97(37)$ & & 1.00 & \\
\hline & allele & $\mathrm{A}$ & $121(66)$ & $167(63)$ & 0.657 & $0.90(0.60-1.33)$ & 0.586 \\
\hline & & $\mathrm{T} / \mathrm{T}$ & $65(72)$ & $95(70)$ & & 1.00 & \\
\hline & genotype & $\mathrm{C} / \mathrm{T}$ & $21(23)$ & $40(30)$ & 0.881 & & 0.764 \\
\hline rs10759932 & & $\mathrm{C} / \mathrm{C}$ & $4(5)$ & $0(0)$ & & $1.09(0.61-1.98)$ & \\
\hline & & $\mathrm{T}$ & $151(84)$ & $230(85)$ & 0.810 & 1.00 & \\
\hline & allele & $\mathrm{C}$ & $29(16)$ & $40(15)$ & & $0.91(0.54-1.52)$ & 0.709 \\
\hline & & $\mathrm{T} / \mathrm{T}$ & $71(77)$ & $111(83)$ & & 1.00 & \\
\hline & genotype & $\mathrm{C} / \mathrm{T}$ & $20(22)$ & $22(17)$ & 0.301 & & 0.241 \\
\hline rs7846989 & & $\mathrm{C} / \mathrm{C}$ & $1(1)$ & $0(0)$ & & $0.67(0.34-1.31)$ & \\
\hline & & $\mathrm{T}$ & $162(88)$ & $244(92)$ & & 1.00 & \\
\hline & allele & $\mathrm{C}$ & $22(12)$ & $22(8)$ & 0.257 & $0.66(0.36-1.24)$ & 0.198 \\
\hline
\end{tabular}

HSP70-heat shock protein 70; TLR2-Toll like receptor 2; TLR4-Toll-like receptor 4; OR—odds ratio; COPD—chronic obstructive pulmonary disease; $\mathrm{CI}$-confidence interval. Allele and genotype distributions are presented as absolute numbers with corresponding percentages. $p^{1}-p$-value were analyzed by $\chi^{2}$ test or Fisher's exact test where appropriate; $p^{2}-p$-value were analyzed by logistic regression. 
Table 7. Association of HSP70 polymorphisms with HSP70 expression.

\begin{tabular}{ccccc}
\hline \multirow{2}{*}{ SNP } & \multirow{2}{*}{ Genotype } & \multicolumn{2}{c}{ HSP70 Expression } & \multirow{2}{*}{$\boldsymbol{p}^{\mathbf{1}}$} \\
\cline { 2 - 4 } & & Controls & COPD & \\
\hline \multirow{3}{*}{ rs1008438 } & $\mathrm{A} / \mathrm{A}$ & $0.90(0.72-1.35)$ & $2.02(1.10-6.84)$ & $<0.001$ \\
& $\mathrm{~A} / \mathrm{C}$ & $1.09(0.76-3.03)$ & $1.72(1.17-12.59)$ & 0.005 \\
& $\mathrm{C} / \mathrm{C}$ & $1.01(0.71-1.38)$ & $1.38(1.07-2.78)$ & 0.099 \\
\cline { 2 - 4 } & $\mathrm{P}^{2}$ & 0.360 & 0.147 & \\
\hline \multirow{2}{*}{ rs1043618 } & $\mathrm{G} / \mathrm{G}$ & $0.90(0.71-1.25)$ & $2.02(1.18-6.84)$ & $<0.001$ \\
& $\mathrm{C} / \mathrm{G}$ & $1.09(0.79-3.92)$ & $1.72(1.16-12.76)$ & 0.008 \\
& $\mathrm{C} / \mathrm{C}$ & $1.13(0.78-1.67)$ & $1.38(1.07-2.78)$ & 0.276 \\
\cline { 2 - 4 } & $\mathrm{P}$ & 0.178 & 0.127 & \\
\hline \multirow{2}{*}{$\mathrm{rs6457452}$} & $\mathrm{C} / \mathrm{C}$ & $0.98(0.73-1.87)$ & $1.83(1.16-10.17)$ & $<0.001$ \\
& $\mathrm{C} / \mathrm{T}$ & $1.31(0.93-1.97)$ & $1.27(0.86-3.79)$ & 0.921 \\
\cline { 2 - 4 } & $\mathrm{T} / \mathrm{T}$ & $3.26(1.01-5.50)$ & - & - \\
\hline
\end{tabular}

SNP—single nucleotide polymorphism; HSP70—-heat shock protein 70; COPD—chronic obstructive pulmonary disease. Results are shown as median (interquartile range). $p^{1}$-difference in $H S P 70$ expression between control group and patients with COPD within the same genotype of HSP70 polymorphisms, checked by Kruskal-Wallis test. $p^{2}$ - difference in $H S P 70$ expression between genotypes of $H S P 70$ polymorphisms in control group and in patients with COPD, checked by Kruskal-Wallis test.

Our previous research demonstrated that COPD patients had increased concentrations of plasma eHsp70 [8], and TLR2 and TLR4 are its main receptors [10]. Therefore, we evaluated the association between HSP70, TLR2 and TLR4 polymorphisms and eHsp70 concentrations (Table S3). COPD patients had increased eHsp70 concentrations compared to controls within the same genotype, while there was no difference in eHsp70 concentrations either in controls or COPD patients when heterozygotes and variant homozygotes were compared to reference homozygotes in terms of each polymorphism.

\subsection{Haplotype Analysis}

All three investigated HSP70 SNPs were in strong LD, meaning that they are expected to be inherited together and therefore were included in the haplotype analysis. Table 8 shows that the $\mathrm{C}_{\mathrm{rs} 1008438} \mathrm{C}_{\mathrm{rs} 1043618} \mathrm{~T}_{\mathrm{rs} 6457452}$ haplotype was associated with COPD risk with OR of $0.47(95 \% \mathrm{CI}=0.23-0.97, p=0.043)$ in comparison to the reference haplotype $\mathrm{A}_{\mathrm{rs} 1008438} \mathrm{G}_{\mathrm{rs} 1043618} \mathrm{C}_{\mathrm{rs} 6457452}$. Two TLR2 polymorphisms were included in LD analysis. However, the $\mathrm{D}^{\prime}$ value between rs3804099 and rs13150331 was 0.65 , so no haplotype analysis was performed due to the applied criterion of $\mathrm{D}^{\prime}>0.80$. Of the three TLR4 SNPs examined, rs2737190 and rs10759932 as well as rs2737190 and rs7846989 were found to be strongly inherited. However, none of the common haplotypes with a frequency $>0.01$ was associated with COPD risk (Table S4).

Table 8. Association analysis of HSP70 haplotypes with COPD risk.

\begin{tabular}{ccccccc}
\hline \multirow{2}{*}{ rs1008438 } & \multirow{2}{*}{ rs1043618 } & \multirow{2}{*}{ rs6457452 } & \multicolumn{2}{c}{ Frequency } & \multirow{2}{*}{ OR (95\% CI) } & $p$ \\
\cline { 4 - 5 } & & & Controls & COPD & & \\
\hline $\mathrm{A}$ & $\mathrm{G}$ & $\mathrm{C}$ & 0.570 & 0.646 & 1.00 & - \\
$\mathrm{C}$ & $\mathrm{C}$ & $\mathrm{C}$ & 0.230 & 0.285 & $1.03(0.66-1.60)$ & 0.910 \\
$\mathrm{C}$ & $\mathrm{C}$ & $\mathrm{T}$ & 0.107 & 0.062 & $0.47(0.23-0.97)$ & 0.043 \\
$\mathrm{C}$ & $\mathrm{G}$ & $\mathrm{C}$ & 0.039 & 0.007 & $0.19(0.04-1.00)$ & 0.052 \\
$\mathrm{~A}$ & $\mathrm{C}$ & $\mathrm{C}$ & 0.035 & 0 & $\mathrm{NA}$ & 1 \\
\hline
\end{tabular}

HSP70-heat shock protein 70; COPD—chronic obstructive pulmonary disease; OR—odds ratio; CI-confidence interval; NA—not applicable. Rare haplotypes $\left(\mathrm{A}_{\mathrm{rs} 1008438} \mathrm{C}_{\mathrm{rs} 1043618} \mathrm{~T}_{\mathrm{rs} 6457452}, \mathrm{C}_{\mathrm{rs} 1008438} \mathrm{G}_{\mathrm{rs} 1043618} \mathrm{~T}_{\mathrm{rs} 6457452}\right.$ and $\mathrm{A}_{\mathrm{rs} 1008438} \mathrm{G}_{\mathrm{rs} 1043618} \mathrm{~T}_{\mathrm{rs} 6457452}$ ) with total frequency $<0.01$ were not included in the association analysis. 


\section{Discussion}

This study showed that the gene expression of HSP70 and TLR2 was increased in COPD patients compared to controls. This increase was independent of COPD severity assessed by both airway obstruction as well as symptoms burden and exacerbation history, and was also independent of the subjects' smoking status. Regarding SNPs analysis, the T allele of HSP70 rs6457452 polymorphism as well as HSP70 haplotype consisting of the rs6457452 T allele had a protective role in COPD. Finally, decreased HSP70 gene expression was observed in COPD C/T carriers of the rs6457452 polymorphism compared to COPD $\mathrm{C} / \mathrm{C}$ homozygotes.

Dong et al. demonstrated increased HSP70 gene expression in the peripheral lung tissues of COPD patients, and the HSP70 expression negatively correlated with lung function which was assessed by $\mathrm{FEV}_{1}$. Moreover, it was observed that expression of Hsp70 protein and its mRNA level was up-regulated by cigarette smoke in vitro in 16HBE human bronchial epithelial cells [12]. In our study, gene expression of HSP70 was increased in peripheral blood cells of COPD patients compared to the controls. We found that HSP70 gene expression amongst COPD patients was independent of their smoking history, and we suggest that observed increase of its level compared to controls was associated with disease itself and not with smoking. However, those conclusions should be taken with caution due to the small number of COPD non-smokers $(n=10)$. In the study by Rumora et al., Hsp70 protein expression was explored in relation to smoking status of both control and COPD subjects. Decreased Hsp70 expression in COPD individuals, especially in COPD smokers, was explained by its potentially increased release from peripheral blood leukocytes [31]. Indeed, we have previously reported increased plasma concentration of eHsp70 in COPD patients compared to healthy individuals [8].

The main eHsp70 receptors TLR2 and TLR4 are activated mostly by pathogen components but can also be activated by proteins released from dying cells, including Hsps that act like DAMPs. Activation of the TLR signaling pathway leads to the production of proinflammatory cytokines [32]. Overall, available data on TLR2 and TLR4 expression are conflicting, and results seem to be by cell type i.e., tissue specific. High gene expression of TLR2 and TLR4 was found in peripheral blood mononuclear cells of obese patients suggesting that up-regulated expression of TLRs is associated with persistent low-grade inflammation [33]. Both TLR2 and TLR4 mRNA levels were increased in circulating neutrophils of COPD patients, and they were also increased in COPD smokers compared to non-smoking controls [34]. Our previous in vitro studies demonstrated that eHsp70 increased only TLR2 but not TLR4 expression in human monocyte-derived macrophages [35]. Similarly, in the current study, TLR2 gene expression was increased in peripheral blood cells of COPD patients, but TLR4 expression in COPD subjects did not differ from the control group. This increase might be associated with increased levels of eHsp70. However, TLR2 is a receptor of many other ligands apart from eHsp70, and further investigation is needed to explore a possible association between TLR2 and eHsp70. TLR2 showed similar pattern of behavior as HSP70 in terms of association with disease severity but not entirely with smoking. TLR2 expression increased only in former COPD smokers and COPD smokers compared with non-smoking controls, and in COPD smokers in comparison to smoking controls. It could be suggested that in stable COPD, especially in COPD smokers, there is a persistent low-grade inflammation that contributes to the increase of HSP70 and TLR2 mRNA levels. In addition, there may be differential transcription of the HSP70 and TLR2 genes in COPD patients, which could finally lead to differential gene expression.

A growing number of large-scale genome-wide association studies, e.g., COPD Gene and International COPD Genetics Consortium, have been trying to identify genetic variants associated with the risk of COPD that might help the diagnosis or become therapeutic targets. However, the heritability of complex diseases, such as COPD, remained unsolved. In order to explore the risk of developing COPD in the Croatian population, a total of nine SNPs of HSP70, TLR2 and TLR4 were genotyped. Only the relatively rare (MAF $=0.08)$ HSP70 rs6457452 SNP, located in the 5'UTR region, showed an association with the risk of 
COPD. SNPs localized in regulatory part of a gene such as the $5^{\prime} \mathrm{UTR}$ region could affect the mRNA stability and expression, contributing to a disease susceptibility [36]. It was reported that rs6457452 was associated with increased risk of COPD in smokers, but the rs6457452 did not follow HWE in that study [13]. However, rs6457453 met the HWE criterion in our study and demonstrated a lower risk of COPD in the $\mathrm{C} / \mathrm{T}$ and $\mathrm{T} / \mathrm{T}$ carriers compared to $\mathrm{C} / \mathrm{C}$ carriers, and the $\mathrm{T}$ allele showed protective effect. In the study by Guo et al. the $\mathrm{T}$ allele of rs6457452 was associated with an increased risk of lung cancer in two independent lung case-control studies within the Chinese population, and they demonstrated that the $\mathrm{T}$ allele was associated with lower Hsp70 protein expression in both normal bronchial epithelial cells and malignant cancer cells [37]. In addition, the C allele of rs6457452 was associated with decreased HSP70 expression in sepsis. The same authors also estimated that the peripheral blood mononuclear cells of individuals with the haplotype consisting of the $\mathrm{C}$ allele of rs6457452 were producing less Hsp70 [38]. Haplotype analysis of HSP70 from this study suggested an association of the haplotype containing the T allele of rs6457452 variant with the protective effect in COPD. When dealing with complex diseases, haplotype analysis is a useful and inexpensive method. Therefore, larger studies with a more detailed, statistically sophisticated assessment needs to be performed to explore further the effect of Hsp70 on the risk of COPD.

Although other polymorphisms studied did not show significant association with COPD risk in our cohort of participants, there were few studies that demonstrated their significant relations. The HSP70 rs1008438 polymorphism was associated with COPD in all COPD subjects and in the smoking subgroup, and smoking parameter pack-years was higher in the COPD C/C carriers in the study by Korytina et al. [3]. In addition, it was reported that the A allele of rs1008438 was associated with increased COPD risk in smoking participants and those who were exposed to biomass burning smoke, but rs1008438 was not related to mRNA or protein levels of Hsp70 [13]. The C/C carriers of the HSP70 rs1043618 were associated with an increased risk of lung cancer [39], and with higher risk of coronary heart disease, while reduced expression of Hsp70 protein was affected by the polymorphism [21]. TLR2 and TLR4 polymorphisms were associated with various conditions such as asthma [40], pulmonary tuberculosis [32,41], Helicobacter pylori infection [42], as well as alterations in levels of high-density lipoprotein cholesterol, low-density lipoprotein cholesterol and triglycerides [36]. They were also associated with susceptibility to COPD [25], the level and decline of lung function, an increased number of inflammatory cells in induced sputum of COPD patients [24], and an increased risk of COPD in smokers [43] or an earlier stage of COPD [44]. However, the ethnic context of polymorphisms as well as sample size should be considered regarding the results of the genetic association studies.

In this study, we found no association between plasma eHsp70 concentrations in COPD patients and selected HSP70, TLR2 and TLR4 polymorphisms. However, HSP70 gene expression was affected by the HSP70 rs6457452 SNP, and COPD patients with $\mathrm{C} / \mathrm{T}$ genotype had reduced gene expression of HSP70 in comparison to those with the $\mathrm{C} / \mathrm{C}$ genotype. Furthermore, there was no difference in HSP70 expression between the controls and COPD subjects within the same $\mathrm{C} / \mathrm{T}$ genotype, suggesting that the $\mathrm{T}$ allele of the rs6457452 polymorphism may have an impact on gene transcription. However, this remains to be confirmed with a larger sample size that would include the COPD patients with $\mathrm{T} / \mathrm{T}$ genotype, and the role of rs6457452 in COPD should be explored in a functional genomic study.

The main limitation of the current study is a small sample size, especially our results regarding the effect of smoking on HSP70 and TLR2 expression, and the association of HSP70 rs6457452 with COPD and HSP70 expression should be taken with caution. Another limitation of our study was the lack of GOLD 1 and GOLD C patients. However, COPD patients in GOLD 1 stage rarely contact physicians due to very mild symptoms, while GOLD C group of patients is also very rare since patients do not have many symptoms and are not frequent exacerbators. 


\section{Conclusions}

To conclude, HSP70 and TLR2 gene expression may have a significant role in the pathogenesis of COPD. The current study is the first to demonstrate that HSP70 rs6457452 polymorphism may affect $H S P 70$ gene expression and may be associated with the risk of COPD in the Croatian population. Thus, identification of specific molecular markers in peripheral circulation of COPD patients could be useful for achieving a better understanding of the systemic component of the disease.

Supplementary Materials: The following are available online at https:/ /www.mdpi.com/article/10 .3390/diagnostics11081412/s1, Table S1: Association of TLR2 polymorphisms with TLR2 expression; Table S2: Association of TLR4 polymorphisms with TLR4 expression; Table S3: Association of HSP70, TLR2 and TLR4 polymorphisms with plasma Hsp70 concentrations; Table S4: Association analysis of TLR4 haplotypes with COPD risk.

Author Contributions: Conceptualization, I.H. and L.R.; methodology, I.H., M.G.R., A.Č., S.D., S.P.-G., M.R.A., J.K., A.F. and L.R.; validation, I.H., M.G.R. and L.R.; formal analysis, I.H. and L.R.; investigation, I.H., M.G.R., S.P.-G., M.R.A., J.K., A.F. and L.R.; resources, S.D., S.P.-G., J.K., A.F. and L.R.; data curation, I.H. and L.R.; writing — original draft preparation, I.H. and L.R.; writing-review and editing, I.H., M.G.R., A.Č., S.D., S.P.-G., M.R.A., J.K., A.F. and L.R.; visualization, I.H. and L.R.; supervision, S.P.-G., L.R.; project administration, L.R.; funding acquisition, L.R. and J.K. All authors have read and agreed to the published version of the manuscript.

Funding: This work has been fully supported by the Croatian Science Foundation under projects number IP-2014-09-1247 and IP-2016-1441. The work of PhD student Iva Hlapčić has been fully supported by the "Young researchers' career development project—-training of doctoral students" of the Croatian Science Foundation funded by the European Union from the European Social Fund.

Institutional Review Board Statement: The study was conducted according to the guidelines of the Declaration of Helsinki and approved by the Ethical Committee of University Hospital Centre Zagreb (02/21/JG on 29 August 2014) and the Ethical Committee for Experimentation of the University of Zagreb Faculty of Pharmacy and Biochemistry (251-62-03-14-78 on 10 September 2014).

Informed Consent Statement: Informed consent was obtained from all subjects involved in the study.

Data Availability Statement: The data presented in this study are available on request from the corresponding author.

Conflicts of Interest: The authors declare no conflict of interest. The funders had no role in the design of the study; in the collection, analyses, or interpretation of data; in the writing of the manuscript, or in the decision to publish the results.

\section{References}

1. Global Initiative for Chronic Obstructive Lung Disease (GOLD). Global Strategy for the Diagnosis, Management, and Prevention of Chronic Obstructive Pulmonary Disease. 2021. Available online: https://goldcopd.org/gold-reports/ (accessed on 2 August 2021).

2. Barnes, P.J. Cellular and molecular mechanisms of asthma and COPD. Clin. Sci. 2017, 131, 1541-1558. [CrossRef]

3. Korytina, G.F.; Akhmadishina, L.Z.; Aznabaeva, Y.G.; Kochetova, O.V.; Zagidullin, N.S.; Kzhyshkowska, J.G.; Zagidullin, S.Z.; Viktorova, T.V. Associations of the NRF2/KEAP1 pathway and antioxidant defense gene polymorphisms with chronic obstructive pulmonary disease. Gene 2019, 692, 102-112. [CrossRef] [PubMed]

4. Barnes, P.J. Inflammatory endotypes in COPD. Allergy Eur. J. Allergy Clin. Immunol. 2019, 74, 1249-1256. [CrossRef]

5. Hlapčić, I.; Somborac-Bačura, A.; Popović-Grle, S.; Vukić Dugac, A.; Rogić, D.; Rako, I.; Žanić Grubišić, T.; Rumora, L. Platelet indices in sfigutr chronic obstructive pulmonary disease-Association with inflammatory markers, comorbidities and therapy. Biochem. Med. 2020, 30, 60-73. [CrossRef] [PubMed]

6. Sarir, H.; Henricks, P.A.J.; van Houwelingen, A.H.; Nijkamp, F.P.; Folkerts, G. Cells, mediators and Toll-like receptors in COPD. Eur. J. Pharmacol. 2008, 585, 346-353. [CrossRef] [PubMed]

7. Hacker, S.; Lambers, C.; Hoetzenecker, K.; Pollreisz, A.; Aigner, C.; Lichtenauer, M.; Mangold, A.; Niederpold, T.; Zimmermann, M.; Taghavi, S.; et al. Elevated HSP27, HSP70 and HSP90 $\alpha$ in chronic obstructive pulmonary disease: Markers for immune activation and tissue destruction. Clin. Lab. 2009, 55, 31-40.

8. Hlapčić, I.; Hulina-Tomašković, A.; Grdić Rajković, M.; Popović-Grle, S.; Vukić Dugac, A.; Rumora, L. Association of Plasma Heat Shock Protein 70 with Disease Severity, Smoking and Lung Function of Patients with Chronic Obstructive Pulmonary Disease. J. Clin. Med. 2020, 9, 3097. [CrossRef] [PubMed] 
9. Ünver, R.; Deveci, F.; Kırkıl, G.; Telo, S.; Kaman, D.; Kuluöztürk, M. Serum heat shock protein levels and the relationship of heat shock proteins with various parameters in chronic obstructive pulmonary disease patients. Turk. Thorac. J. 2016, 17, 153-159. [CrossRef]

10. Asea, A.; Rehli, M.; Kabingu, E.; Boch, J.A.; Baré, O.; Auron, P.E.; Stevenson, M.A.; Calderwood, S.K. Novel signal transduction pathway utilized by extracellular HSP70. Role of toll-like receptor (TLR) 2 and TLR4. J. Biol. Chem. 2002, 277, 15028-15034. [CrossRef]

11. Kiang, J. Heat Shock Protein 70 kDa Molecular Biology, Biochemistry, and Physiology. Pharmacol. Ther. 1998, 80, 183-201. [CrossRef]

12. Dong, J.; Guo, L.; Liao, Z.; Zhang, M.; Zhang, M.; Wang, T.; Chen, L.; Xu, D.; Feng, Y.; Wen, F. Increased expression of heat shock protein 70 in chronic obstructive pulmonary disease. Int. Immunopharmacol. 2013, 17, 885-893. [CrossRef]

13. Ambrocio-Ortiz, E.; Pérez-Rubio, G.; Ramírez-Venegas, A.; Hernández-Zenteno, R.; Del Angel-Pablo, A.D.; Pérez-Rodríguez, M.E.; Salazar, A.M.; Abarca-Rojano, E.; Falfán-Valencia, R. Effect of SNPs in HSP Family Genes, Variation in the mRNA and Intracellular Hsp Levels in COPD Secondary to Tobacco Smoking and Biomass-Burning Smoke. Front. Genet. 2020, $10,1307$. [CrossRef]

14. Hulina-Tomašković, A.; Heijink, I.H.; Jonker, M.R.; Somborac-Bačura, A.; Grdić Rajković, M.; Rumora, L. Pro-inflammatory effects of extracellular Hsp70 and cigarette smoke in primary airway epithelial cells from COPD patients. Biochimie 2019, 156, 47-58. [CrossRef]

15. Haw, T.J.; Starkey, M.R.; Pavlidis, S.; Fricker, M.; Arthurs, A.L.; Nair, P.M.; Liu, G.; Hanish, I.; Kim, R.Y.; Foster, P.S.; et al. Toll-like receptor 2 and 4 have opposing roles in the pathogenesis of cigarette smoke-induced chronic obstructive pulmonary disease. Am. J. Physiol. Lung Cell. Mol. Physiol. 2018, 314, L298-L317. [CrossRef] [PubMed]

16. Von Scheele, I.; Larsson, K.; Dahlén, B.; Billing, B.; Skedinger, M.; Lantz, A.S.; Palmberg, L. Toll-like receptor expression in smokers with and without COPD. Respir. Med. 2011, 105, 1222-1230. [CrossRef]

17. Esther, C.R.; Alexis, N.E.; Picher, M. Regulation of airway nucleotides in chronic lung diseases. Subcell. Biochem. 2015, 55, 75-93.

18. Zhou, W.; Wang, Y. Candidate genes of idiopathic pulmonary fibrosis: Current evidence and research. Appl. Clin. Genet. 2016, 9, 5-13. [PubMed]

19. Aquino-Gálvez, A.; González-Ávila, G.; Pérez-Rodríguez, M.; Partida-Rodríguez, O.; Nieves-Ramírez, M.; Piña-Ramírez, I.; Ramírez-Martínez, G.; Castillejos-López, M.; Checa, M.; Ruiz, V.; et al. Analysis of heat shock protein 70 gene polymorphisms Mexican patients with idiopathic pulmonary fibrosis. BMC Pulm. Med. 2015, 15, 129. [CrossRef] [PubMed]

20. Dulin, E.; García-Barreno, P.; Guisasola, M.C. Genetic variations of HSPA1A, the heat shock protein levels, and risk of atherosclerosis. Cell Stress Chaperones 2012, 17, 507-516. [CrossRef] [PubMed]

21. He, M.; Guo, H.; Yang, X.; Zhang, X.; Zhou, L.; Cheng, L.; Zeng, H.; Hu, F.B.; Tanguay, R.M.; Wu, T. Functional SNPs in HSPA1A gene predict risk of coronary heart disease. PLoS ONE 2009, 4, e4851. [CrossRef] [PubMed]

22. Matokanović, M.; Rumora, L.; Popović-Grle, S.; Čepelak, I.; Čulić, O.; Barišić, K. Association of hsp70-2 (+1267A/G), hsp70-hom $(+2437 \mathrm{~T} / \mathrm{C}), \mathrm{HMOX}-1$ (number of GT repeats) and TNF-alpha (+489G/A) polymorphisms with COPD in Croatian population. Clin. Biochem. 2012, 45, 770-774. [CrossRef] [PubMed]

23. Dai, Y.; Zhang, Z.; Xu, L.; Shang, Y.; Lu, R.; Chen, J. Genetic polymorphisms of IL17A, TLR4 and P2RX7 and associations with the risk of chronic obstructive pulmonary disease. Mutat. Res. Genet. Toxicol. Environ. Mutagen. 2018, 829-830, 1-5. [CrossRef] [PubMed]

24. Budulac, S.E.; Boezen, H.M.; Hiemstra, P.S.; Lapperre, T.S.; Vonk, J.M.; Timens, W.; Postma, D.S. Toll-Like Receptor (TLR2 and TLR4) Polymorphisms and Chronic Obstructive Pulmonary Disease. PLoS ONE 2012, 7. [CrossRef] [PubMed]

25. Li, Z.; Mao, X.; Liu, Q.; Song, H.; He, B.; Shi, P.; Zhang, Q.; Li, X.; Wang, J. Functional variations of the TLR4 gene in association with chronic obstructive pulmonary disease and pulmonary tuberculosis. BMC Pulm. Med. 2019, 19, 184. [CrossRef]

26. Rio, D.C.; Ares, M.; Hannon, G.J.; Nilsen, T.W. Purification of RNA Using TRIzol (TRI Reagent). Cold Spring Harb. Protoc. 2010, 2010, db-prot5439. [CrossRef]

27. Hlapčić, I.; Hulina-Tomašković, A.; Somborac-Bačura, A.; Rajković, M.G.; Dugac, A.V.; Popović-Grle, S.; Rumora, L. Extracellular adenosine triphosphate is associated with airflow limitation severity and symptoms burden in patients with chronic obstructive pulmonary disease. Sci. Rep. 2019, 9, 15349. [CrossRef]

28. Livak, K.J.; Schmittgen, T.D. Analysis of Relative Gene Expression Data Using Real-Time Quantitative PCR and the $2^{-\Delta \Delta C T}$ Method. Methods 2001, 25, 402-408. [CrossRef]

29. Miller, S.A.; Dykes, D.D.; Polesky, H.F. A simple salting out procedure for extracting DNA from human nucleated cells. Nucleic Acids Res. 1988, 16, 1215. [CrossRef]

30. Li, C.; Li, Y.; Yan, Z.; Dai, S.; Liu, S.; Wang, X.; Wang, J.; Zhang, X.; Shi, L.; Yao, Y. Polymorphisms in endoplasmic reticulum aminopeptidase genes are associated with cervical cancer risk in a Chinese Han population. BMC Cancer 2020, 20, 341. [CrossRef]

31. Rumora, L.; Milevoj, L.; Popović-Grle, S.; Barišić, K.; Grubišić, T.Ž.; Čepelak, I. Reduction in peripheral blood leukocyte heat shock proteins 27 and 70 expression in chronic obstructive pulmonary disease. Croat. Chem. Acta 2008, 81, 73-80.

32. Zhou, Y.; Zhang, M. Associations between genetic polymorphisms of TLRs and susceptibility to tuberculosis: A meta-analysis. Innate Immun. 2020, 26, 75-83. [CrossRef] 
33. Ahmad, R.; Al-Mass, A.; Atizado, V.; Al-Hubail, A.; Al-Ghimlas, F.; Al-Arouj, M.; Bennakhi, A.; Dermime, S.; Behbehani, K. Elevated expression of the toll like receptors 2 and 4 in obese individuals: Its significance for obesity-induced inflammation. $J$. Inflamm. 2012, 9, 1-11. [CrossRef] [PubMed]

34. Tripathi, P.M.; Kant, S.; Yadav, R.S.; Kushwaha, R.A.S.; Prakash, V.; Rizvi, S.H.M.; Parveen, A.; Mahdi, A.A.; Ahmad, I. Expression of Toll-like Receptor 2 and 4 in Peripheral Blood Neutrophil Cells from Patients with Chronic Obstructive Pulmonary Disease. Oman Med. J. 2017, 32, 477-485. [CrossRef]

35. Hulina-Tomašković, A.; Somborac-Bačura, A.; Grdić Rajković, M.; Bosnar, M.; Samaržija, M.; Rumora, L. Effects of extracellular Hsp70 and cigarette smoke on differentiated THP-1 cells and human monocyte-derived macrophages. Mol. Immunol. 2019, 111, 53-63. [CrossRef] [PubMed]

36. Gomes Torres, A.C.M.B.; Leite, N.; Tureck, L.V.; de Souza, R.L.R.; Titski, A.C.K.; Milano-Gai, G.E.; Lazarotto, L.; da Silva, L.R.; Furtado-Alle, L. Association between Toll-like receptors (TLR) and NOD-like receptor (NLR) polymorphisms and lipid and glucose metabolism. Gene 2019, 685, 211-221. [CrossRef]

37. Guo, H.; Deng, Q.; Wu, C.; Hu, L.; Wei, S.; Xu, P.; Kuang, D.; Liu, L.; Hu, Z.; Miao, X.; et al. Variations in HSPA1B at 6p21.3 are associated with lung cancer risk and prognosis in Chinese populations. Cancer Res. 2011, 71, 7576-7586. [CrossRef]

38. Kee, C.; Cheong, K.Y.; Pham, K.; Waterer, G.W.; Temple, S.E.L. Genetic variation in heat shock protein 70 is associated with septic shock: Narrowing the association to a specific haplotype. Int. J. Immunogenet. 2008, 35, 465-473. [CrossRef] [PubMed]

39. Wang, Y.; Zhou, F.; Wu, Y.; Xu, D.; Li, W.; Liang, S. The relationship between three Heat shock protein 70 gene polymorphisms and susceptibility to lung cancer. Clin. Chem. Lab. Med. 2010, 48, 1657-1663. [CrossRef]

40. Gao, Y.; Xiao, H.; Wang, Y.; Xu, F. Association of single-nucleotide polymorphisms in toll-like receptor 2 gene with asthma susceptibility. Medicine 2017, 96, e6822. [CrossRef]

41. Wang, M.; Xu, G.; Lü, L.; Xu, K.; Chen, Y.; Pan, H.; Burstrom, B.; Burstrom, K.; Wang, J. Genetic polymorphisms of IL-17A, IL-17F, TLR4 and miR-146a in association with the risk of pulmonary tuberculosis. Sci. Rep. 2016, 6, 1-12. [CrossRef]

42. Mirkamandar, E.; Nemati, M.; Hayatbakhsh, M.M.; Bassagh, A.; Khosravimashizi, A.; Jafarzadeh, A. Association of a single nucleotide polymorphism in the TLR2 gene (rs3804099), but not in the TLR4 gene (rs4986790), with Helicobacter pylori infection and peptic ulcer. Turk. J. Gastroenterol. 2018, 29, 283-291. [CrossRef] [PubMed]

43. Speletas, M.; Merentiti, V.; Kostikas, K.; Liadaki, K.; Minas, M.; Gourgoulianis, K.; Germenis, A.E. Association of TLR4-T399I Polymorphism with Chronic Obstructive Pulmonary Disease in Smokers. Clin. Dev. Immunol. 2009, 2009, 1-6. [CrossRef] [PubMed]

44. Apostolou, A.; Kerenidi, T.; Michopoulos, A.; Gourgoulianis, K.I.; Noutsias, M.; Germenis, A.E.; Speletas, M. Association between TLR2/TLR4 gene polymorphisms and COPD phenotype in a Greek cohort. Herz 2017, 42, 752-757. [CrossRef] [PubMed] 